\title{
Religion and Corporate Innovation
}

\author{
Meng Wang ${ }^{1} \&$ Lining Gan $^{2}$ \\ ${ }^{1}$ Sydney Institution of Language of Commerce, Shanghai University, Shanghai, China \\ ${ }^{2}$ Sydney Institution of Language of Commerce, Shanghai University, Shanghai, China \\ Correspondence: Meng Wang, Sydney Institution of Language of Commerce, Shanghai University, Shanghai, China.
}

Received: February 7, 2018

doi:10.11114/bms.v4i1.3001

\author{
Accepted: February 25, 2018 \\ Online Published: February 26, 2018 \\ URL: https://doi.org/10.11114/bms.v4i1.3001
}

\begin{abstract}
Innovation ability is an important factor to measure firms' strength and is vital to the long-term development of the enterprises, previous studies have shown that financial position and corporate governance can have effects on corporate innovation, but put little attention on the informal system which may influence on innovation. This article selects religion as one of the informal system and tries to explore the impact of religion on the innovation input and output of enterprises. Using the data of A-sh are listed companies from 2008 to 2015, the empirical results show that there is a significantly positive correlation between religion and innovation inputs and outputs, and this positive correlation between religion and innovation is negatively regulated by the politics and marketization index. The results prove that politics and marketization index are substitution of religion on corporate innovation. In further analysis, the religion is divided into eastern and western parts, the results show that both eastern and western religions can promote corporate innovation, but the promotion effect of western religions is stronger. Negative moderating effect of political and marketization index on the positive correlation between religion and innovation still exists, and basically showing a more forceful inhibitory effect made by western religions on corporate innovation.
\end{abstract}

Keywords: corporate innovation, religion, politics, Marketization Index

\section{Introduction}

The originator of technological innovation theory is Joseph Alois Schumpeter, who first proposed the theory of innovation in his book "economic development theory" in 1912. Schumpeter believes that "innovation" is to recombine production factors and production conditions and introduce them into production system, that is to establish a new production function, and its purpose is to get potential profits. Innovation is more important in the era of rapid development of information technology. Firms will not be eliminated and have a sustainable development only in the way that they can win out in a fierce competitive environment, and innovation ability is a key factor for long-term development of enterprises. Nowadays, enterprises are faced with competition in technological and innovative capabilities. The most fundamental way for enterprises to continuously drive value growth and keep competitive advantage for a long time is to continue effective technological innovation. Turning over the history of the famous enterprises, the success history of Apple, Intel, TOYOTA, SIEMENS, Lenovo and HUAWEI is the process of constantly technological innovations. The innovation ability of a company is also a country's innovation ability. Therefore, both enterprises and countries attach great importance to innovation, and focus on improving their innovation capability.

The decision of innovation investment is ultimately carried out by human beings who make decisions depended on objective conditions even their personal value and preference, therefore human behavior decision is a complex process. As a result, it is not enough to study the impact of internal governance and external environment on innovation only. Culture can also affect investment decisions of innovation through influencing management's values and outlook on life. On the other hand, the influence of religion on corporate governance is mostly about public goods contribution, corporate social responsibility, financial violation and earnings management. Only few and incomplete literature has mentioned the discussion of religion and corporate innovation. In this case, this article tries to study the influence of religion on corporate innovation and try to make up the gap in this academic field. Does religion promote or restrain innovation and what is the transmission mechanism? Is there any difference about the influences between eastern and western religion? Are there any changes in the impact of religion on corporate innovation under different institutional backgrounds? Those are the problems that this article needs to solve. 
The main contributions of this paper are as follows: (1) it enriches the research on the influencing factors of corporate innovation. Previous studies show that corporate innovation will be affected by the nature of the enterprise, the industry, business performance and company internal governance, external government intervention and market factors. This paper tries to study the influence of religion as an informal system on corporate innovation. It has greatly enriched the research on the influencing factors of corporate innovation. (2) It provides evidence for the effect of informal system on corporate micro activities. Religion, as a carrier of culture, is an important informal system, which will permeate the individual's outlook on life and values, and affect people's investment decision-making behavior. This paper explores the influence of religion on corporate innovation, which helps to understand how religious belief and different religion types act on micro economic activities.

\section{Literature Review}

Enterprise innovation is affected by many factors, generally speaking mainly in two aspects, the desire for innovation and innovation ability, innovation ability is mainly reflected in the company's financial indicators, large-scale of enterprises is the major force to promote industrial innovation, and innovation ability of large enterprises is bigger than that of small ones, the larger size of the enterprise, the more innovation activities are conducted (Acs \& Audretsch, 1998; Vaona \& Pianta, 2008; Kam , Kiese,Singh \&Wong, 2003; Shefer \& Frenkel, 2005). Along with the increase of leverage, the interest expense will squeeze the cash flow, so the rise of the debt ratio will have a certain impact on the technological innovation activities (Baysinger \& Hoski-sson, 1989).

The desire of innovation is mainly embodied in the property of enterprises and internal governance. As the age of enterprises grows, enterprises will accumulate experiences and knowledge which are necessary for innovation, which means that there is a positive correlation between the corporate age and innovation (Sorensen \& Stuart, 2000). However, older enterprises have established settled procedures and routines, which are not conducive to respond to external technological progress, so big age will also constitute obstacles to technological innovation. A lot of enterprise innovation decisions will greatly affected by the corporate attributes, since when the government holds all or the vast proportion of the ownership, the corporate innovation enthusiasm will be weakened. Overly relying on the traditional mode of economic growth, corporations lack motivation in innovation which can decrease product cost and improve product quality (Hart \& Shleifer, 1997; Ng, Yuce \& Chen, 2009). Besides, internal corporate governance also affects innovation a lot. Fernandes (2008), Dong and Gou (2010) believes that if the independent director number accounted for all directors with higher rates, R\&D investment proposal will get more support from senior decision makers. But the size of the board is negatively related to innovation value (Mak \& Kusnadi, 2005). Moreover, the innovation output and efficiency are also affected by the input. Research and development investment is divided into personnel input and capital input, since the personnel input data is difficult to obtain, academic research focuses on the R\&D input. Domestic and foreign scholars' conclusions about the impact of $R \& D$ on corporate innovation are relatively uniform. It is agreed that $R \& D$ investment is an important factor to promote innovation output (Scherer, 1965).

Empirical studies of the relationship between religion and corporate behavior are still rare (McGuire et al., 2012). One of the biggest difficulties is the measurement of religious traditions (religious beliefs) and their differences. Some people in the academic community have tried to get data using a questionnaire survey, Mcguire, Omer and Sharp (2011) investigated the influence of religion on respondents from three aspects: cognition, influence and behavior based on 610,000 questionnaires. As a result, there is a significant negative relationship between religion and irregularities in financial reporting and where external supervision is weaker, the impact of religion is stronger. Weaver and Agle (2002) argue that there is enough reason to believe that religion does affect ethical behavior of organizations. How to find out the relationship in an empirical way poses a great challenge to all scholars. How to solve this problem, the academic community has been constantly exploring. Tracing back, the company's behavior is decided and enforced by individuals especially company executives who participate in the company's contract. Therefore it seems that the aggregation of personal beliefs of employees or executives is the best measure, but it is not easy. Even in the United States, where religion is "a field where data is rich and complete in social sciences," data on the individual religious beliefs of employees in companies are not available to avoid the suspicion of "religious discrimination" ( Iannaccone, 1998).

In recent years, some scholars have attempted to use the religious environment of the company's location to measure the religious impact on the company. The model of how a social custom established by Akerlof (1980) affects individual behavior shows that for a given code of conduct, the more people in a society recognize and follow this code of behavior, the more motivation drives individuals in society to follow the code. As a result, companies located in areas of high religious beliefs are also more likely to have their management and staff obey those codes of conduct associated with religion, so that the religious norms in place can have a social impact and are likely to affect the attitude and corporate culture of headquartered local companies (McGuire et al., 2011).

Chen, Hu, Liang, Xin and University (2013) pointed out in Religious Tradition and Corporate Governance that the 
informal system of religion can significantly improve the quality of corporate governance. The stronger the religious atmosphere, which is mainly reflected in the location of the listed company, the fewer irregularities, the lower the earnings management and the fewer the non-standard audit report. Moreover, this relationship is more obvious in areas where the law environment is better, indicating that the law (formal system) and the religious tradition (informal system) have certain complementary relationship. Du and Feng (2014) found that the probability and intensity of corporate donations is positively related to religion, and political factors can weaken the positive correlation, revealing the reciprocal effect of religion and political linkages on corporate donations. Using data from the United States, Hilary and Hui (2009) demonstrated that religious intensity is negatively correlated with R\&D investment. Lei, Liu and Cao (2016) use the direct survey data of entrepreneurs 'religious beliefs to examine the impact of entrepreneurs' personal religious beliefs on the investment activities. The study find that compared with $R \& D$ investment, religious believers prefer to invest in less risky relational investments. To conclude, it is difficult to draw a consistent conclusion since there is little research on the impact of religion and innovation domestic and overseas. This article attempts to systematically explore the relationship between the religion and innovation for the first time.

\section{Hypotheses Development}

Different religions have different doctrines, which in turn have different effects on innovation. On the whole, the impact of religion on business innovation has both incentive and restraint mechanisms. Specifically, religion as a culture first influences the preferences of firms in terms of risk and competition preferences. Radical religious cultures are good for innovation, while risk-averse religious cultures inhibit innovation. In addition, the institutional attributes of religion accumulate social capital, which can indirectly affect enterprise innovation. Furthermore, religion can also affect the innovation through the accumulation of human capital and short-term and long-term preferences.

\subsection{Restraint Mechanism}

First of all, religion as a culture, the impact on people mostly about values, outlook on life and other spiritual level, religion can influence business innovation investment or decision-making by risk appetite and competition preferences. As Iannaccone (1998) points out in his Introduction to Religious Economics and Introduction to Religious Economics, "Religion creates values and beliefs that further affect economic behavior and decision-making ".

The studies of scholars also provide evidence for different risk appetite of religion. Studies have shown that the reason that people choose religious beliefs is related to their characteristics or personality, to be precise, people seek belief for dependence and security. Rokeach (1968) proves that individuals with faith are easier to be more anxious, and Lerner and Keltener (2001) find that anxiety can lead to risk averse behavior for individuals. Dyreng, Mayew and Williams (2012) found that Catholics often avoid risk, and the impact of religion on social norms in the company's area is negatively correlated with the financial reporting dynamics. Hilary \& Hui (2009) found that the higher the proportion of religious believers in the workforce, the more inclined the managers are to risk aversion. Companies located in areas with high levels of religious affiliation have a more pronounced overall risk aversion compared with those located in less religious areas.

\subsection{Incentive Mechanism}

Religion, as an organizational form, helps to shape social capital and thus has an indirect impact on business innovation. Enterprise innovation needs a lot of capital investment, so the constraints of credit has also become an innovation constraint. Social capital, as an informal financial channel, can be used as a supplement or alternative to formal corporate finance. And group activities such as religious worship can greatly promote the formation of social capital. Coupled with the fact that religions place more emphasis on mutual care and assistance among believers than other secular groups, such social capital established within religious fellowships may be more solid.

Many religions pursue the harmony between people. For example, Taoism pursues the harmonious state of harmony between man and nature, including both the harmony between man and nature and the harmony between people. Oriental religious culture pays attention to the introvert, taking harmony of nature as truth, interpersonal harmony as good, and harmony of nature and man as beauty. In the Christian doctrine, there are a great deal of space devoted to tolerance, patience and philanthropism, there is a special chapter in the bible about "love the enemy," such as "Biblical Mafia 5: 38-48, 7:12; Luke 6: 27-36), we can see that Christianity in the west is very valued about the love between people.

In the study of religion and trust, many studies show that religious belief has a significant positive influence on the formation of trust. Studies by Johansson-Stenman, Mahmud and Martinsson (2009) support this argument and point out that Hindu and Muslim believers trust more people with the same beliefs compared with people with different ones. Porta, Shleifer and Vishny (1997) argue that trust can promote the formation of a horizontal cooperation network, which in turn enhances the performance of the organization (including the firm). Therefore, non-hierarchical religion can 
improve corporate performance by promoting interpersonal trust within the organization and promoting horizontal cooperation. In addition, more and more studies show that religion has the function of social support and social security (Lelkes, 2002) also use the data in our country to prove that religious beliefs are good for entrepreneurship. The main reason for this positive influence may be that religious beliefs have changed entrepreneurial preferences while the social capital built by religious organizations has relaxed entrepreneurial constraints.

Furthermore, in addition to social capital, religion has a significant impact on the accumulation of human capital, and human capital is crucial for innovation's input and output. Therefore, religion may affect enterprise innovation by affecting human capital. Glaeser and Glendon (1998) use the US GSS survey data from 1972 to 1994, regarding educated years as a measure of secular economic success, found that Christians and Presbyterians were stronger related secular success compared to Catholic believers. Gruber (2005) uses religious market density as a tool for religious participation based on the US GSS and census data, found that religions have a significantly positive effect on education attainment. Put forward a mechanism by which Christianity affects the education level. That is, Protestantism emphasizes the importance of Bible study and greatly increases the literacy rate of believers so as to promote the improvement of human capital. Therefore, if religion is conducive to the accumulation of human capital, there is no question that it will enhance the innovation capability of enterprises.

In the end, both eastern and western religions prefer to have a long-term aspiration, because believers of religions want to pursue some eternal things. The ascension of Christianity, the reincarnation of Buddhism or Taoism cultivation, all of them suggest that afterlife conditions are related to performance in this life. Through extensive research into the religious beliefs and investment strategies of business decision makers, Lei et al (2016) found that religious decision makers are more likely to make long-term business improvements rather than pursue a momentary benefit compared with business decision makers without religious beliefs. Therefore, in the long-term perspective, religion can promote innovation.

Based on the theoretical analysis above, it can be seen that religion has both the incentive and the restraining effect on enterprise innovation. Therefore, the following assumptions are put forward:

H1a: Religion is positively related to innovation.

H1b: Religion is negatively related to innovation.

If $\mathrm{H} 1 \mathrm{a}$ is true, it provides evidence that the incentive mechanism, which means the stimulating effect of social capital, human capital, and long-term vision on business innovation, prevails suppressed mechanism. The same regression results are expected in different religion categories, since incentive mechanisms share similar characteristics in both eastern and western region. But if $\mathrm{H} 1 \mathrm{~b}$ is true, the inhibition mechanism of religious risk aversion prevails incentive mechanism. It can be predicted that the suppression effect on innovation by eastern religions will be stronger than western religions since the degree of risk aversion by eastern religions exceeds western ones.

$\boldsymbol{H 2 a}$ : Eastern and western religions are both positively related to innovation.

$\boldsymbol{H} 2 \boldsymbol{b}$ : Both eastern and western religions are negatively related to innovation, and eastern religions will have a greater inhibitory effect on innovation than western ones.

Politically connected companies can often get access to some scarce resources through some special channel, no matter under what kind of system, political connections can always have a significant impact on corporate decision-making. Enterprises can use their political relationships to make private property less infringement, reduce corporate non-compliance penalties, to help businesses get out of the woods. Having political connection is somewhat like adding a layer of protective film, firms can acquire scarce resources and reduce the impact of the uncertainties of external environment. Religious beliefs are also somehow a kind of self-protection sought by firms. Therefore, it is predicted that political factors may be an alternative to religion and reduce the influence of religion as an informal system on enterprise innovation. Therefore, H3:

H3: Compared companies with non-political connection, religion has a weaker impact on innovation of firms with political connection.

The degree of marketization is a measure of the share of market factors in the allocation of social resources. After the reform and opening up, China gradually transformed itself from a planned economy to a market-oriented economy. The central government gradually reduced its power to regulate and control economic activities. By studying the degree of marketization in different regions, we can understand the process of market-oriented economic development from a quantitative perspective. Sun and Zhan (2016) conducted an empirical study on the panel data of marketization, cultural mobility and innovation performance in 30 provinces in China, and concluded that the degree of marketization in a region is a positive factor for their ability to innovate. Because marketization as a formal system is a powerful catalyst 
for innovation in economies within the region, thus marketization may have a weakened effect on the relationship between religion and innovation. Therefore, this paper proposes the hypothesis H4:

H4: compared companies in a lower degree of marketization area, religion has a weaker impact on innovation of firms in a higher degree of marketization area.

\section{Methodology}

\subsection{Empirical Specification}

In order to verify the relationship between religion and business innovation, the paper established a basic model (1). The dependent variable is innovation, in which $R$ \& $D$ represents $R$ \& D investment, Patents is the output of $R \& D$ represented by the output of patents, and Religion represents the number of religious places around listed companies registered. In order to test the influence of politics and marketization on the relationship between religion and business innovation, models (2) and (3) are established in this paper. In order to further analyze whether East-West religion has different direction or extent of influence on business innovation, this paper repeats models (1), (2) and (3). Simultaneously, Religion is replaced by subdivision of east and west.

$$
\mathrm{R} \& \mathrm{D} / \text { Patent }=\beta 0+\beta 1 \mathrm{Re} \text { ligion }+\sum_{i} r_{i} \text { Control }+\varepsilon
$$

$$
\begin{aligned}
& \mathrm{R} \& \mathrm{D} / \text { Patent }=\beta 0+\beta 1 \text { Religion }+\beta 2 \text { Political }+\beta 3 \text { Religion } * \text { Political }+\sum_{i} r_{i} \text { Controli }+\varepsilon \\
& \mathrm{R} \& \mathrm{D} / \text { Patent }=\beta 0+\beta 1 \text { Religion }+\beta 2 \text { Market }+\beta 3 \text { Religion } * \text { Market }+\sum_{i} r_{i} \text { Controli }+\varepsilon
\end{aligned}
$$

In the aspect of quantifying religious Intensity, this article draws lessons from $\mathrm{Du}$, using the number of temples or churches around listed companies as an indicator of religious strength. This paper divides innovation into two aspects: investment and output. Innovation investment is measured by the ratio of R\&D to operating income. Innovation output is measured by the application of the patent.

Table 1. The definition and calculation of independent and dependent variables

\begin{tabular}{c|l|c|l}
\hline & variable Name & Variable Symbol & \multicolumn{1}{c}{ Variable Definition } \\
\hline $\begin{array}{c}\text { Dependent } \\
\text { variables }\end{array}$ & $\begin{array}{l}\text { Innovation } \\
\text { input }\end{array}$ & R\&D & R \& D expenditures / operating income \\
\cline { 2 - 4 } & $\begin{array}{l}\text { Innovation } \\
\text { output }\end{array}$ & Patent & $\begin{array}{l}\text { Logarithm of the 1 plus total number of patent } \\
\text { applications }\end{array}$ \\
\hline \multirow{4}{*}{$\begin{array}{c}\text { Independent } \\
\text { variable }\end{array}$} & Religion in all & $\begin{array}{c}\text { R100Z、R200Z、 } \\
\text { R300Z }\end{array}$ & $\begin{array}{l}\text { The number of temples or churches within a } \\
100,200,300 \mathrm{~km} \text { radius of a listed company }\end{array}$ \\
\cline { 2 - 5 } & $\begin{array}{c}\text { Eastern } \\
\text { religion }\end{array}$ & $\begin{array}{c}\text { East100、 } \\
\text { East200、East300 }\end{array}$ & $\begin{array}{l}\text { The number of eastern temples within a 100,200,300 km } \\
\text { radius of a listed company }\end{array}$ \\
\cline { 2 - 5 } & $\begin{array}{c}\text { Western } \\
\text { religion }\end{array}$ & $\begin{array}{c}\text { West100、 } \\
\text { West200、West300 }\end{array}$ & $\begin{array}{l}\text { The number of western churches within a 100,200,300 } \\
\text { km radius of a listed company }\end{array}$ \\
\hline
\end{tabular}

In the selection of control variables, this article selected more comprehensive indicators. (I) Financial indicators of the company: firm size, cash ratio, sales, growth, Leverage and ratio of profits to cost (Cost). (II) Corporate Governance indicators: total shareholdings of the top ten shareholders (Top10), LNBoard, Independent, dual position of board chairman and CEO (CEO). In addition set the industry and the year as the controlled dummy variables.

Politics and marketization index are selected as moderating variables. This article defines Board directors, supervisory directors or senior executives are deputies or CPPCC members or above as a political affiliation. The marketization index adopts the "China Marketization Index - 2011 Report on the Relative Process of Marketization of Provinces and Districts" compiled by Fan Gang et al. (2009), and use market-based calculation of Dongdong et al (2012) measures the marketization index after 2010. According to the marketization index for 2003-2009 provided by Fan Gang et al., The index for 2010 is calculated by the index of 2009 plus the index value average added for the preceding six years from 2003 to 2009. 
Table 2. Definition and calculation of control variables

\begin{tabular}{l|l}
\hline Variable Symbol & \multicolumn{1}{c}{ Variable Definition } \\
\hline Size & The logarithm of toal asset \\
\hline Cash & percentage of "cash / total assets" \\
\hline Sales & The logarithm of sales \\
\hline Growth & $\begin{array}{l}100 * \text { (Revenue for the year - Revenue for the previous year) / Revenue for the } \\
\text { previous year }\end{array}$ \\
\hline leverage & $100 *$ (Liabilities / Total Assets) \\
\hline Cost & $100 *$ (operating profit / cost total cost $)$ \\
\hline Top10 & Percentage of total shareholdings of the top ten shareholders \\
\hline LNAge & $\begin{array}{l}\text { The logarithm of the number of years from the establishment of the year to the } \\
\text { year of data selection }\end{array}$ \\
\hline LNBoard & The logarithm of the total board size \\
\hline Independent & Number of Independent Directors \\
\hline CEO & 1 for dual position of board chairman and CEO, 0 otherwise \\
\hline Industry & $\begin{array}{l}\text { Controlled industry dummy variable, 1 for manufacturing industry, } \\
\text { otherwise }\end{array}$ \\
\hline Year & Controlled year dummy variable, 1 for 2008, 0 otherwise \\
\hline Political & $\begin{array}{l}\text { If the position of Board directors supervisory directors or senior executives } \\
\text { are deputies or CPPCC members or above, it is defined as a political } \\
\text { affiliation, named 1, otherwise 0 }\end{array}$ \\
\hline Market & Marketization process index of Fan Gang et al (2011) \\
\hline
\end{tabular}

This article chooses the data of listed companies on the main board from 2008 to 2015, the reason for choosing 2008 as the cut-off point is that the relevant political data in the CSMAR database were only disclosed after 2008 years and many R\&D investment ratio numbers before 2008 were missing. All data is from CSMAR and WIND database. The Growth Enterprises Market (GEM), financial firms and some missing data are deleted, in order to eliminate the impact of abnormal value, this paper makes $1 \%$ Winsorize processing on the major continuous variables, and finally obtains 13809sample data, of which 1337 in 2008 and 1418 in 2009 1,640 in 2010, 1,793 in 2011, 1,879 in 2012, 1,879 in 2013, 1940 in 2014, and 1923 in 2015.

The data on religion were collected by hand and the number of places of worship around listed companies was used as the intensity of the religious atmosphere. Use Google Earth, Baidu maps and other information tools to manually collect the latitude and longitude of the selected firms and latitude and longitude of 756 well-known places of worship to calculate the numbers of religious places around listed companies registered 100,200 and $300 \mathrm{~km}$. Following method of the Du (2013), the latitude and longitude of the temple (company) is represented by lonr and latr (lonf and latf) respectively. $d$ represents the distance between the place of incorporation and the place of worship.

$$
\begin{gathered}
\cos \theta=\sin \text { lat }_{r} \times \sin \text { lat }_{f}+\cos \text { lat }_{r} \times \cos \text { lat }_{f} \times \cos \left(\text { lon }_{r}-\text { lon }_{f}\right) \\
\operatorname{Rad}=(40075.04 / 360) *(180 / \pi) \\
d=\operatorname{rad} \times\left(\Pi / 2-\arctan \left(\cos \theta / \sqrt{1-\cos ^{2} \theta}\right)\right)
\end{gathered}
$$

Temple selection criteria:(1) 142 Nationalities Buddhist temples shorted for "Key Buddhist temple" in the Han Chinese region listed in the appendix to the "Report of the Religious Affairs Bureau of the State Council on Determining the Buddhist Temple and Taoism in the Han Nationality Region" which was authorized by The State Council of the People's Republic of China in April 9, 1983; (2) In April 1983, 21 state-level key temples of Taoism, approved by the State Council of the People's Republic of China, referred to as "the key Taoist temples of Taoism" (State Council, 1983); (3) The award-winning religious sites in the first and second "Advanced Collective and Individual Temples to Establish a Harmonious Temple Temple in China" voted by the Bureau of Ethnic and Religious Affairs in 2010 and 2013 are referred to as "award-winning religious sites" (State Religious Affairs Bureau, 2010 \& 2013) . In consideration of the repeatability, 756 places of worship, referred to as "well-known places of worship", were finally organized and used to calculate the indicators of religious tradition's influence.

\section{Results and Discussion}

\subsection{Religion and Innovation}

On the basis of the model (1), the impact of religion on R \& D investment and patent output is verified by OLS regression. The regression results are shown in Table 3 and 4. The coefficients of R100Z, R200Z and R300Z are 0.074, 0.052 and 0.044 , respectively, and the $t$ values are 9.176, 6.401 and 5.417, respectively. And as the number of kilometers 
becomes larger, that is, the religious atmosphere becomes lower, both the correlation coefficient and the value of $t$ gradually decrease, which conforms to our expectation that the stronger atmosphere the greater effects and is consistent with hypothesis H1a. In addition, from the results of the control variables, both firm size and cash ratio contribute to $\mathrm{R}$ \& while Sales and growth is significantly negatively correlated with R \& D. It may be because the company is in a period of rapid growth, other funding needs of development in addition to R\&D is more intense, such as operation support. Leverage is negatively correlated with $\mathrm{R} \& \mathrm{D}$, which is consistent with the findings of most scholars. The higher leverage, the higher financial risk, the more cautious innovation and investment decisions are made. The coefficient of Cost represented Industry threshold and innovation is negative but not obvious significant. It shows that the higher the threshold of the industry, the relatively safe position of the enterprise and the relative decrease in R \& D. Some internal governance variables have no significant correlation to R \& D, such as Top10, LNBoard and Independent, while dual position of board chairman and CEO is significantly promote the R \& D investment, proving that the promoting effect made by reduction of agency costs on innovation is very obvious.

As with R \& D investment, religion is significantly and positively correlated with the output of patents, and as the number of local mile kilometers registered by listed companies increases, the coefficient and the degree of significance are gradually decreasing. As shown in Table 4, the coefficients of R100Z, R200Z and R300Z are 0.047, 0.039 and 0.033, respectively, and the $t$ values are 5.912, 4.890 and 4.219, respectively.

Table 3. Regression result of religious tradition and R\&D input

\begin{tabular}{|c|c|c|c|}
\hline Variables & \multicolumn{3}{|c|}{ R\&D } \\
\hline R100Z & $\begin{array}{c}0.074 * * * \\
(9.176)\end{array}$ & & \\
\hline R200Z & & $\begin{array}{c}0.052^{* * *} * \\
(6.401)\end{array}$ & \\
\hline R300Z & & & $\begin{array}{c}0.044 * * * \\
(5.417)\end{array}$ \\
\hline Size & $\begin{array}{c}0.182 * * * \\
(10.233)\end{array}$ & $\begin{array}{c}0.182^{* * * *} \\
(10.198)\end{array}$ & $\begin{array}{c}0.181 * * * \\
(10.152)\end{array}$ \\
\hline Cash & $\begin{array}{c}0.103 * * * \\
(11.343)\end{array}$ & $\begin{array}{c}0.105^{* * *} \\
(11.544)\end{array}$ & $\begin{array}{c}0.105^{* * *} \\
(11.612)\end{array}$ \\
\hline Sales & $\begin{array}{c}-0.226^{* * *} \\
(-13.216)\end{array}$ & $\begin{array}{c}-0.223 * * * \\
(-13.035)\end{array}$ & $\begin{array}{c}-0.222 * * * \\
(-12.956)\end{array}$ \\
\hline Growth & $\begin{array}{l}-0.014^{*} \\
(-1.792)\end{array}$ & $\begin{array}{l}-0.015^{*} \\
(-1.840)\end{array}$ & $\begin{array}{l}-0.015^{*} \\
(-1.865)\end{array}$ \\
\hline leverage & $\begin{array}{c}-0.212^{* * *} \\
(-21.103)\end{array}$ & $\begin{array}{c}-0.214^{* * *} \\
(-21.261)\end{array}$ & $\begin{array}{c}-0.215^{* * *} \\
(-21.310)\end{array}$ \\
\hline Cost & $\begin{array}{c}-0.014 \\
(-1.550)\end{array}$ & $\begin{array}{c}-0.015 \\
(-1.629)\end{array}$ & $\begin{array}{l}-0.015^{*} \\
(-1.660)\end{array}$ \\
\hline Top10 & $\begin{array}{c}0.005 \\
(0.555)\end{array}$ & $\begin{array}{c}0.008 \\
(0.869)\end{array}$ & $\begin{array}{c}0.009 \\
(0.983)\end{array}$ \\
\hline LNAge & $\begin{array}{c}-0.011 \\
(-1.246)\end{array}$ & $\begin{array}{c}-0.013 \\
(-1.443) \\
\end{array}$ & $\begin{array}{c}-0.012 \\
(-1.331) \\
\end{array}$ \\
\hline LNBoard & $\begin{array}{c}-0.010 \\
(-0.846)\end{array}$ & $\begin{array}{c}-0.012 \\
(-1.027)\end{array}$ & $\begin{array}{c}-0.013 \\
(-1.066)\end{array}$ \\
\hline Independent & $\begin{array}{c}0.019 \\
(1.550) \\
\end{array}$ & $\begin{array}{c}0.019 \\
(1.604) \\
\end{array}$ & $\begin{array}{c}0.019 \\
(1.554)\end{array}$ \\
\hline $\mathrm{CEO}$ & $\begin{array}{c}0.068^{* * * *} \\
(8.259)\end{array}$ & $\begin{array}{c}0.069^{* * *} \\
(8.361)\end{array}$ & $\begin{array}{c}0.069 * * * \\
(8.410)\end{array}$ \\
\hline Industry & - & - & - \\
\hline Year & - & - & - \\
\hline Intercept & $\begin{array}{c}2.771 * * * \\
(4.371)\end{array}$ & $\begin{array}{c}2.877^{* * * *} \\
(4.528)\end{array}$ & $\begin{array}{c}2.887 \\
(4.536)\end{array}$ \\
\hline Number of Obs & 13226 & 13226 & 13226 \\
\hline Adj-R $^{2}$ & 0.163 & 0.160 & 0.159 \\
\hline $\mathrm{F}$ & $184.590 * * *$ & $180.922 * * *$ & 179.935 \\
\hline
\end{tabular}


Table 4. Regression result of religious tradition and patent output

\begin{tabular}{|c|c|c|c|}
\hline Variables & Patent & & \\
\hline R100Z & $\begin{array}{l}0.047 * * * \\
(5.912)\end{array}$ & & \\
\hline R200Z & & $\begin{array}{l}0.039 * * * \\
(4.890)\end{array}$ & \\
\hline R300Z & & & $\begin{array}{l}0.033 * * * \\
(4.219)\end{array}$ \\
\hline Size & $\begin{array}{l}0.078 * * * \\
(4.497)\end{array}$ & $\begin{array}{l}0.079 * * * \\
(4.537)\end{array}$ & $\begin{array}{l}0.079^{* * * *} \\
(4.511)\end{array}$ \\
\hline Cash & $\begin{array}{l}0.034 * * * \\
(3.871)\end{array}$ & $\begin{array}{l}0.036^{* * *} \\
(4.012)\end{array}$ & $\begin{array}{l}0.036^{* * * *} \\
(4.069)\end{array}$ \\
\hline Sales & $\begin{array}{l}0.147^{* * * *} \\
(8.774)\end{array}$ & $\begin{array}{l}0.147^{* * * *} \\
(8.785)\end{array}$ & $\begin{array}{l}0.148^{* * * *} \\
(8.823)\end{array}$ \\
\hline Growth & $\begin{array}{l}-0.021 * * * \\
(-2.716)\end{array}$ & $\begin{array}{l}-0.021 * * * \\
(-2.734)\end{array}$ & $\begin{array}{l}-0.022 * * * \\
(-2.752)\end{array}$ \\
\hline leverage & $\begin{array}{l}-0.102^{* * * *} \\
-10.359\end{array}$ & $\begin{array}{l}-0.103^{* * *} \\
-10.454\end{array}$ & $\begin{array}{l}-0.103^{* * *} \\
-10.493\end{array}$ \\
\hline Cost & $\begin{array}{l}-0.024^{* * *} \\
(-2.686)\end{array}$ & $\begin{array}{l}-0.025^{* * *} \\
(-2.732)\end{array}$ & $\begin{array}{l}-0.025^{* * *} \\
(-2.756)\end{array}$ \\
\hline Top10 & $\begin{array}{l}0.028 * * * \\
(3.158)\end{array}$ & $\begin{array}{l}0.029 * * * \\
(3.335)\end{array}$ & $\begin{array}{l}0.030^{* * *} \\
(3.421)\end{array}$ \\
\hline LNAge & $\begin{array}{l}-0.071 * * * \\
(-8.251)\end{array}$ & $\begin{array}{l}-0.072 * * * \\
(-8.349)\end{array}$ & $\begin{array}{l}-0.071 * * * \\
(-8.246)\end{array}$ \\
\hline LNBoard & $\begin{array}{l}0.010 \\
(0.869)\end{array}$ & $\begin{array}{l}0.009 \\
(0.742)\end{array}$ & $\begin{array}{l}0.008 \\
(0.710)\end{array}$ \\
\hline Independent & $\begin{array}{l}0.023^{* *} \\
(1.981)\end{array}$ & $\begin{array}{l}0.024 * * \\
(2.065)\end{array}$ & $\begin{array}{l}0.024^{* *} \\
(2.031)\end{array}$ \\
\hline $\mathrm{CEO}$ & $\begin{array}{l}0.064 * * * \\
(7.948)\end{array}$ & $\begin{array}{l}0.064 * * * \\
(8.016)\end{array}$ & $\begin{array}{l}0.065^{* * * *} \\
(8.054)\end{array}$ \\
\hline Industry & - & - & - \\
\hline Year & - & - & - \\
\hline Intercept & $\begin{array}{l}-4.462 * * * \\
(-14.680)\end{array}$ & $\begin{array}{l}-4.448 * * * \\
(-14.621)\end{array}$ & $\begin{array}{l}-4.447 * * * \\
(-14.599)\end{array}$ \\
\hline Number of Obs & 13226 & 13226 & 13226 \\
\hline Adj-R ${ }^{2}$ & 0.199 & 0.198 & 0.198 \\
\hline $\mathrm{F}$ & 235.354 & 234.372 & 233.828 \\
\hline
\end{tabular}

Note: $* * *, * *, *$ represents $1 \%, 5 \%, 10 \%$ of the significance level, respectively, with $\mathrm{t}$ value in the brackets.

\subsection{Politics, Religion and Innovation}

Based on the model (2), we add the political connection to carry out the OLS regression and attempt to explore the moderated effect of politics on the relationship between religion and enterprise innovation. The results are shown in Table 5. The coefficients of R100Z * Political on R \& D input and patent output are -0.061 and -0.058 respectively, with $\mathrm{t}$ values of -3.372 and -3.260 , respectively. The coefficients of $\mathrm{R} 200 \mathrm{Z} *$ Political for $\mathrm{R} \& \mathrm{D}$ inputs and patent outputs are -0.057 and -0.049 , respectively, with $t$ values of -3.213 and -2.807 , respectively. The coefficients of R300Z * Political for R\&D inputs and patent outputs are -0.053 and -0.059 , respectively, with $t$ values of -2.905 and -3.326 , respectively. This results show a weakened effect of politics on the positive correlation between religious and R \& D inputs and patent output, proving that the politics and informal systems religion is a alternative relationship. Hypothesis $\mathrm{H} 3$ is validated by the decline in religious promotion of business innovation among politically connected firms compared with non-politically connected firms. 
Table 5. The Effect of Politics on the Relationship between Religion and Enterprise Innovation

\begin{tabular}{|c|c|c|c|c|c|c|}
\hline Variables & \multicolumn{3}{|l|}{ R\&D } & \multicolumn{3}{|l|}{ Patent } \\
\hline R100Z & $\begin{array}{l}0.107 * * * \\
(8.423)\end{array}$ & & & $\begin{array}{l}0.078^{* * *} \\
(6.271)\end{array}$ & & \\
\hline $\mathrm{R} 200 \mathrm{Z}$ & & $\begin{array}{l}0.082^{* * *} \\
(6.640)\end{array}$ & & & $\begin{array}{l}0.064 * * * \\
(5.305)\end{array}$ & \\
\hline $\mathrm{R} 300 \mathrm{Z}$ & & & $\begin{array}{l}0.071 * * * \\
(5.777)\end{array}$ & & & $\begin{array}{l}0.063 * * * \\
(5.253)\end{array}$ \\
\hline Political & $\begin{array}{l}0.030^{* *} \\
(1.991)\end{array}$ & $\begin{array}{l}0.026^{*} \\
(1.764)\end{array}$ & $\begin{array}{l}0.024 \\
(1.550)\end{array}$ & $\begin{array}{l}0.056^{* * *} \\
(3.792)\end{array}$ & $\begin{array}{l}0.049 * * * \\
(3.362)\end{array}$ & $\begin{array}{l}0.057 * * * \\
(3.793)\end{array}$ \\
\hline $\begin{array}{l}\text { R100Z*Poli } \\
\text { tical }\end{array}$ & $\begin{array}{l}-0.061^{* * *} \\
(-3.372)\end{array}$ & & & $\begin{array}{l}-0.058^{* * *} \\
(-3.260)\end{array}$ & & \\
\hline $\begin{array}{l}\text { R200Z*Poli } \\
\text { tical }\end{array}$ & & $\begin{array}{l}-0.057 * * * \\
(-3.213)\end{array}$ & & & $\begin{array}{l}-0.049 * * * \\
(-2.807)\end{array}$ & \\
\hline $\begin{array}{l}\text { R300Z*Poli } \\
\text { tical }\end{array}$ & & & $\begin{array}{l}-0.053 * * * \\
(-2.905)\end{array}$ & & & $\begin{array}{l}-0.059 * * * \\
(-3.326)\end{array}$ \\
\hline Intercept & $\begin{array}{l}2.644 * * * \\
(4.166)\end{array}$ & $\begin{array}{l}2.774 * * * \\
(4.363)\end{array}$ & $\begin{array}{l}2.780^{* * *} \\
(4.365)\end{array}$ & $\begin{array}{l}-4.493 * * * \\
(-14.770)\end{array}$ & $\begin{array}{l}-4.463 * * * \\
(-14.663)\end{array}$ & $\begin{array}{l}-4.472 * * * \\
(-14.673)\end{array}$ \\
\hline $\begin{array}{l}\text { Number of } \\
\text { Obs }\end{array}$ & 13226 & 13226 & 13226 & 13226 & 13226 & 13226 \\
\hline Adj-R ${ }^{2}$ & 0.163 & 0.161 & 0.160 & 0.200 & 0.199 & 0.198 \\
\hline $\mathrm{F}$ & 162.539 & 159.278 & 158.278 & 207.027 & 205.926 & 205.693 \\
\hline
\end{tabular}

\subsection{Marketization Index, Religion and Innovation}

Based on the model (3), we add the index of marketization index to OLS regression and try to explore the regulatory effect of marketization index on the relationship between religion and firm innovation. The result is shown in Table 6 . The marketization index shows the same trend with the politics, significantly boosting R \& D spending and patent output. This shows that the larger the marketization index- a more perfect market, the greater input and output of innovation. However, there is a significantly negative correlation between innovation and the cross items of marketization index and religion. The coefficients of R100Z * Market for R \& D input and patent output are -0.282 and -0.284 respectively, with $\mathrm{t}$ values of -6.177 and -6.320 , respectively; The coefficients of R200Z * Market for R \& D input and patent output are -.310 and -.402 respectively, with $t$ values of -6.195 and -8.190 , respectively; The coefficients of $\mathrm{R} 300 \mathrm{Z} *$ Market for R \& D input and patent output are -0.291 and -386 respectively, with $\mathrm{t}$ values of -6.058 and -8.185 , respectively. It shows that the formal system of market index and the informal system of religion are a substitute for each other. In places where the degree of marketization is low, religion has a strong promoting effect on the innovation of enterprises. Where the degree of marketization is high, Promotion effect is weakened which has verified hypothesis $\mathrm{H} 4$.

Table 6. The Effect of Marketization Index on the Relationship between Religion and Enterprise Innovation

\begin{tabular}{|c|c|c|c|c|c|c|}
\hline Variables & R\&D & & & Patent & & \\
\hline R100Z & $\begin{array}{l}0.235^{* * *} \\
(6.097)\end{array}$ & & & $\begin{array}{l}0.242^{* * *} \\
(6.393)\end{array}$ & & \\
\hline R200Z & & $\begin{array}{l}0.208^{* * *} \\
(4.957)\end{array}$ & & & $\begin{array}{l}0.319^{* * *} \\
(7.742)\end{array}$ & \\
\hline R300Z & & & $\begin{array}{l}0.185^{* * *} \\
(4.690)\end{array}$ & & & $\begin{array}{l}0.295^{* * *} \\
(7.609)\end{array}$ \\
\hline Market & $\begin{array}{l}0.186^{* * *} \\
(11.978)\end{array}$ & $\begin{array}{l}0.225^{* * *} \\
(13.576)\end{array}$ & $\begin{array}{l}0.229^{* * *} \\
(13.444)\end{array}$ & $\begin{array}{l}0.130^{* * *} \\
(8.556)\end{array}$ & $\begin{array}{l}0.171 * * * \\
(10.508)\end{array}$ & $\begin{array}{l}0.181 * * * \\
(10.833)\end{array}$ \\
\hline $\begin{array}{l}\text { R100Z*Mar } \\
\text { ket }\end{array}$ & $\begin{array}{l}-0.282 * * * \\
(-6.177)\end{array}$ & & & $\begin{array}{l}-0.284 * * * \\
(-6.320)\end{array}$ & & \\
\hline $\begin{array}{l}\text { R200Z*Mar } \\
\text { ket }\end{array}$ & & $\begin{array}{l}-0.310 \text { *** } \\
(-6.195)\end{array}$ & & & $\begin{array}{l}-0.402^{* * * *} \\
(-8.190)\end{array}$ & \\
\hline $\begin{array}{l}\text { R300Z*Mar } \\
\text { ket }\end{array}$ & & & $\begin{array}{l}-0.291 * * * \\
(-6.058)\end{array}$ & & & $\begin{array}{l}-0.386^{* * *} \\
(-8.185)\end{array}$ \\
\hline Intercept & $\begin{array}{l}1.218^{*} \\
(1.873)\end{array}$ & $\begin{array}{l}1.146^{*} \\
(1.754) \\
\end{array}$ & $\begin{array}{l}1.203^{*} \\
(1.837)\end{array}$ & $\begin{array}{l}-5.077 * * * \\
(-16.229)\end{array}$ & $\begin{array}{l}-5.263 * * * \\
(-16.756)\end{array}$ & $\begin{array}{l}-5.272 * * * \\
(-16.751)\end{array}$ \\
\hline $\begin{array}{l}\text { Number of } \\
\text { Obs }\end{array}$ & 13226 & 13226 & 13226 & 13226 & 13226 & 13226 \\
\hline Adj-R ${ }^{2}$ & 0.173 & 0.174 & 0.174 & 0.203 & 0.205 & 0.205 \\
\hline$F$ & 173.329 & 174.573 & 174.706 & 211.620 & 213.683 & 213.739 \\
\hline
\end{tabular}




\subsection{Further Analysis with Distinction Between Eastern and Western Religions}

\subsubsection{Eastern and Western Religions and Innovation}

In order to further probe into the direction and extent of east and west religious influence on innovation input and output, whether there is any difference or not, in the further analysis, the article divides religion into eastern and western parts. Among them, Eastern religions include Buddhism and Taoism, while Western religions include Islam Religion, Catholicism and Christianity. Repeat the model (1), (2) and (3) and find the following results.\#

Repeating the model (1), we can see from the table 7 and 8 that there is a positive correlation between the eastern and western religions for the firm's R \& D investment and innovation output, which confirms the hypothesis H2a in this paper. That is to say, religion promotes innovation and there is no difference between eastern and western religions. Because when the motivational mechanism plays a major role, the doctrines of different religions tend to be the same, therefore the results of different religions are the same. The incentive mechanism of social capital, human capital and long-term preferences promote the innovation greater than suppression mechanism of the risk aversion. However, the promotion effect of western religion on innovation is generally greater than that of eastern religion. As shown in the table 7, the coefficients of West100, West200 and West300 in the regression of East-West religion and R \& D investment are respectively 0.073, 0.073 and 0.040, while the coefficients of East100, East200 and East300 are 0.066, 0.048 and 0.042 . It can be seen that the coefficients of West100 and West200 are respectively larger than those of East100 and East200, while the West300 coefficient is slightly lower than that of East300. This result can also be seen from the table 8 . The coefficients of West100, West200, and West300 in the regression between East-West religions and innovation output are $0.056,0.050$ and 0.044 respectively, which are respectively higher than those of East100, East200 and East300, 0.036, 0.029 and 0.024. This shows that although the motivation mechanism in eastern and western religions all play a leading role in the impact of innovation, Western religions can further promote the trust of interpersonal relationships, the accumulation of social capital and the appeal to the long-term vision as manifested by a stronger promoting effect of Western religion on innovation .

Table 7. The result of the regression between Eastern and Western religions and Enterprise Innovation Input

\begin{tabular}{|c|c|c|c|c|c|c|}
\hline Variables & R\&D & & & & & \\
\hline East100 & $\begin{array}{l}0.066^{* * *} \\
(8.173)\end{array}$ & & & & & \\
\hline East200 & & $\begin{array}{l}0.048 * * * \\
(5.925)\end{array}$ & & & & \\
\hline East300 & & & $\begin{array}{l}0.042 * * * \\
(5.235)\end{array}$ & & & \\
\hline West100 & & & & $\begin{array}{l}0.073 * * * \\
(9.058)\end{array}$ & & \\
\hline West200 & & & & & $\begin{array}{l}0.052 * * * \\
(6.444)\end{array}$ & \\
\hline West300 & & & & & & $\begin{array}{l}0.040 * * * \\
(4.980)\end{array}$ \\
\hline Intercept & $\begin{array}{l}2.819 * * * \\
(4.442)\end{array}$ & $\begin{array}{l}2.897 * * * \\
(4.557)\end{array}$ & $\begin{array}{l}2.905 * * * \\
(4.565)\end{array}$ & $\begin{array}{l}2.858 * * * \\
(4.511)\end{array}$ & $\begin{array}{l}2.924 * * * \\
(4.606)\end{array}$ & $\begin{array}{l}2.941 * * * \\
(4.624)\end{array}$ \\
\hline Number of Obs & 13226 & 13226 & 13226 & 13226 & 13226 & 13226 \\
\hline Adj-R ${ }^{2}$ & 0.162 & 0.160 & 0.159 & 0.163 & 0.160 & 0.159 \\
\hline & 183.114 & 180.424 & 179.771 & 184.408 & 180.970 & 179.550 \\
\hline
\end{tabular}

Table 8 . The result of the regression between Eastern and Western religions and Enterprise Innovation Output

\begin{tabular}{|c|c|c|c|c|c|c|}
\hline Variables & Patent & & & & & \\
\hline East100 & $\begin{array}{l}0.036^{* * * *} \\
(4.508)\end{array}$ & & & & & \\
\hline East200 & & $\begin{array}{l}0.029 * * * * \\
(3.679)\end{array}$ & & & & \\
\hline East300 & & & $\begin{array}{l}0.024^{* * *} * \\
(2.990)\end{array}$ & & & \\
\hline West100 & & & & $\begin{array}{l}0.056^{* * * *} \\
(7.062)\end{array}$ & & \\
\hline West200 & & & & & $\begin{array}{l}0.050^{* * * *} \\
(6.357)\end{array}$ & \\
\hline West300 & & & & & & $\begin{array}{l}0.044 * * * \\
(5.620)\end{array}$ \\
\hline Intercept & $\begin{array}{l}-4.430 * * * \\
(-14.567)\end{array}$ & $\begin{array}{l}-4.419 * * * \\
(-14.521)\end{array}$ & $\begin{array}{l}-4.410 * * * \\
(-14.476)\end{array}$ & $\begin{array}{l}-4.457 * * * \\
(-14.689)\end{array}$ & $\begin{array}{l}-4.461 * * * \\
(-14.687)\end{array}$ & $\begin{array}{l}-4.471 * * * \\
(-14.699)\end{array}$ \\
\hline Number of Obs & 13226 & 13226 & 13226 & 13226 & 13226 & 13226 \\
\hline Adj-R ${ }^{2}$ & 0.198 & 0.197 & 0.197 & 0.200 & 0.199 & 0.199 \\
\hline $\mathrm{F}$ & 234.052 & 233.448 & 233.039 & 236.682 & 235.840 & 235.055 \\
\hline
\end{tabular}




\subsubsection{Politics, Eastern and Western Religion and Innovation}

Repeat the model (2), add the political association for OLS regression, trying to explore the regulatory effect of politics on the relationship between eastern and western religions and business innovation, the results are shown in the table 9 and 10. All the cross terms of religions and politics are negatively correlated with firm innovation input and output, indicating that in politically connected firms, religion is less likely to promote innovation in firms than in non-politically connected firms which proves hypothesis $\mathrm{H} 3$. The absolute value of the cross terms of religion and politics in the west is generally greater than that in the east. The stronger weakened impact imposed by western religion shows a stronger alternative of politics and western religions.

Table 9. The Effect of Political Connection on the Relationship between Eastern and Western Religion and Enterprise Innovation Input

\begin{tabular}{|c|c|c|c|c|c|c|}
\hline Variables & R\&D & & & & & \\
\hline East 100 & $\begin{array}{l}0.089 * * * \\
(7.051)\end{array}$ & & & & & \\
\hline East 200 & & $\begin{array}{l}0.073 * * * \\
(5.963)\end{array}$ & & & & \\
\hline East300 & & & $\begin{array}{l}0.066^{* * * *} \\
(5.377)\end{array}$ & & & \\
\hline West100 & & & & \begin{tabular}{|l}
$0.116^{* * * *}$ \\
$(9.013)$ \\
\end{tabular} & & \\
\hline West200 & & & & & \begin{tabular}{|l}
$0.086^{* * * *}$ \\
$(7.010)$ \\
\end{tabular} & \\
\hline West300 & & & & & & $\begin{array}{l}0.068 * * * \\
(5.615)\end{array}$ \\
\hline Political & $\begin{array}{l}0.014 \\
(0.968) \\
\end{array}$ & $\begin{array}{l}0.016 \\
(1.163)\end{array}$ & $\begin{array}{l}0.015 \\
(1.082)\end{array}$ & $\begin{array}{l}0.042 * * \\
(2.783) \\
\end{array}$ & \begin{tabular}{|l}
$0.036^{* *}$ \\
$(2.325)$ \\
\end{tabular} & $\begin{array}{l}0.028^{*} \\
(1.760)\end{array}$ \\
\hline East $100 *$ Political & $\begin{array}{l}-0.040^{* *} \\
(-2.348)\end{array}$ & & & & & \\
\hline East200*Political & & $\begin{array}{l}-0.046^{* * *} \\
(-2.722)\end{array}$ & & & & \\
\hline East300*Political & & & $\begin{array}{l}-0.044^{* * * *} \\
(-2.538)\end{array}$ & & & \\
\hline West100*Political & & & & $\begin{array}{l}-0.078^{* * *} \\
(-4.302)\end{array}$ & & \\
\hline West $200 *$ Political & & & & & \begin{tabular}{|l}
$-0.067 * * *$ \\
$(-3.690$ \\
\end{tabular} & \\
\hline West300*Political & & & & & & $\begin{array}{l}-0.056^{* * *} \\
-3.065\end{array}$ \\
\hline Intercept & $\begin{array}{l}2.733^{* * * *} \\
4.303\end{array}$ & $\begin{array}{l}2.818^{* * * *} \\
4.431\end{array}$ & $\begin{array}{l}2.820 * * * \\
4.429\end{array}$ & $\begin{array}{l}2.698^{* * * *} \\
4.255\end{array}$ & \begin{tabular}{|l}
$2.789^{* * * *}$ \\
4.389
\end{tabular} & $\begin{array}{l}2.818^{* * * *} \\
4.426\end{array}$ \\
\hline Number of Obs & 13226 & 13226 & 13226 & 13226 & \begin{tabular}{|l|}
13226 \\
\end{tabular} & 13226 \\
\hline Adj-R $R^{2}$ & 0.162 & 0.160 & 0.160 & \begin{tabular}{|l|l|}
0.164 \\
\end{tabular} & \begin{tabular}{|l|}
0.161 \\
\end{tabular} & 0.160 \\
\hline $\mathrm{F}$ & 160.816 & 158.637 & 157.992 & 162.904 & \begin{tabular}{|l|}
159.536 \\
\end{tabular} & 157.994 \\
\hline
\end{tabular}


Table 10. The Effect of Political Connection on the Relationship between Eastern and Western Religion and Enterprise Innovation Output

\begin{tabular}{|c|c|c|c|c|c|c|}
\hline Variables & \multicolumn{6}{|c|}{ Patent } \\
\hline East 100 & $\begin{array}{l}0.052 * * * \\
(4.236)\end{array}$ & & & & & \\
\hline East200 & & $\begin{array}{c}0.053^{* * *} \\
(4.406)\end{array}$ & & & & \\
\hline East300 & & & $\begin{array}{c}0.050^{* * * *} \\
(4.177)\end{array}$ & & & \\
\hline West100 & & & & $\begin{array}{c}0.106^{* * *} \\
(8.399)\end{array}$ & & \\
\hline West200 & & & & & $\begin{array}{c}0.075^{* * *} \\
(6.209)\end{array}$ & \\
\hline West300 & & & & & & $\begin{array}{c}0.074 * * * \\
(6.231)\end{array}$ \\
\hline Political & $\begin{array}{c}0.035^{* *} \\
(2.540)\end{array}$ & $\begin{array}{c}0.044 * * * \\
(3.251)\end{array}$ & $\begin{array}{c}0.049 * * * \\
(3.502)\end{array}$ & $\begin{array}{c}0.079 * * * \\
(5.359)\end{array}$ & $\begin{array}{c}0.051^{* * *} \\
(3.315)\end{array}$ & $\begin{array}{c}0.059^{* * * *} \\
(3.837)\end{array}$ \\
\hline East100*Political & $\begin{array}{l}-0.029^{*} \\
(-1.752)\end{array}$ & & & & & \\
\hline East $200 *$ Political & & $\begin{array}{c}-0.044 * * * \\
(-2.686)\end{array}$ & & & & \\
\hline East300*Political & & & $\begin{array}{c}-0.050 * * * \\
(-2.981)\end{array}$ & & & \\
\hline West $100 *$ Political & & & & $\begin{array}{c}-0.090^{* * * *} \\
(-5.093)\end{array}$ & & \\
\hline West $200 *$ Political & & & & & $\begin{array}{c}-0.048^{* * *} \\
(-2.701) \\
\end{array}$ & \\
\hline West $300 *$ Political & & & & & & $\begin{array}{c}-0.060^{* * *} \\
(-3.356)\end{array}$ \\
\hline Intercept & $\begin{array}{l}4.436^{* * *} \\
(-14.573) \\
\end{array}$ & $\begin{array}{c}-4.426 * * * \\
(-14.537)\end{array}$ & $\begin{array}{c}-4.423 * * * \\
(-14.513)\end{array}$ & $\begin{array}{c}-4.518^{* * *} \\
(-14.883) \\
\end{array}$ & $\begin{array}{c}-4.484 * * * \\
(-14.747) \\
\end{array}$ & $\begin{array}{r}-4.505^{* * *} \\
(-14.795) \\
\end{array}$ \\
\hline Number of Obs & 13226 & 13226 & 13226 & 13226 & 13226 & 13226 \\
\hline Adj-R ${ }^{2}$ & 0.198 & 0.198 & 0.198 & 0.201 & 0.200 & 0.199 \\
\hline $\mathrm{F}$ & 205.292 & 205.061 & 204.836 & 209.398 & 207.193 & 206.792 \\
\hline
\end{tabular}

5.4.3 Marketization Index, Eastern and Western Religion and Innovation

Repeat the model (3), adding marketization index for OLS regression and try to explore the regulatory effect of marketization index on the relationship between eastern and western religion and innovation. The results are shown in Table 11 and 12. The cross terms of East-West religion and marketization index are significantly negatively correlated with the input and output of enterprises innovation, indicating that the formal system of marketization index and the informal system of religion are a substitute for each other. In areas of low marketization, Religion has a strong role in promoting enterprise innovation, but in a more market-oriented area, this promotion has weakened which verified hypothesis H4. Different from the political connection, only the absolute value of the cross-term coefficient of the western religion and the marketization index is greater than that of eastern religion in terms of the output of innovation, which proves that the marketization index has an more strongly weakened impact on the western religion and enterprise innovation, showing a stronger alternative between marketization and western religions. 
Table 11. The Effect of Marketization Index on the Relationship between Eastern and Western Religion and Enterprise Innovation Input

\begin{tabular}{|c|c|c|c|c|c|c|}
\hline Variables & R\&D & & & & & \\
\hline East100 & $\begin{array}{l}0.263 * * * \\
(6.823)\end{array}$ & & & & & \\
\hline East200 & & $\begin{array}{l}0.249^{* * *} \\
(5.758)\end{array}$ & & & & \\
\hline East300 & & & $\begin{array}{l}0.184^{* * * *} \\
(4.370)\end{array}$ & & & \\
\hline West100 & & & & $\begin{array}{l}0.147 * * * \\
(3.877) \\
\end{array}$ & & \\
\hline West200 & & & & & $\begin{array}{l}0.155^{* * * *} \\
(3.972)\end{array}$ & \\
\hline West300 & & & & & & $\begin{array}{l}0.196^{* * *} \\
(5.148)\end{array}$ \\
\hline Market & $\begin{array}{l}0.201^{* * *} \\
(13.281)\end{array}$ & $\begin{array}{l}0.228^{* * *} \\
(14.384)\end{array}$ & $\begin{array}{l}0.223 * * * \\
(13.738) \\
\end{array}$ & $\begin{array}{l}0.146^{* * *} \\
(10.190)\end{array}$ & $\begin{array}{l}0.207^{* * *} \\
(12.025)\end{array}$ & $\begin{array}{l}0.222^{* * *} \\
(12.661)\end{array}$ \\
\hline East $100 *$ Market & $\begin{array}{l}-0.325 * * * \\
(-7.192)\end{array}$ & & & & & \\
\hline East200*Market & & $\begin{array}{l}-0.353 * * * \\
(-6.949)\end{array}$ & & & & \\
\hline East300*Market & & & $\begin{array}{l}-0.287 * * * \\
(-5.771)\end{array}$ & & & \\
\hline West100*Market & & & & $\begin{array}{l}-0.154 * * * \\
(-3.523)\end{array}$ & & \\
\hline West200*Market & & & & & $\begin{array}{l}-0.238^{* * * *} \\
(-4.976)\end{array}$ & \\
\hline West300*Market & & & & & & $\begin{array}{l}-0.282 * * * \\
(-6.055)\end{array}$ \\
\hline Intercept & $\begin{array}{l}1.161^{*} \\
(1.793)\end{array}$ & $\begin{array}{l}1.126^{*} \\
(1.732)\end{array}$ & \begin{tabular}{|l}
$1.314^{* *}$ \\
$(2.016)$ \\
\end{tabular} & $\begin{array}{l}1.645^{* *} \\
(2.532)\end{array}$ & $\begin{array}{l}1.287^{* *} \\
(1.963)\end{array}$ & $\begin{array}{l}1.131^{*} \\
(1.721)\end{array}$ \\
\hline Number of Obs & 13226 & 13226 & 13226 & 13226 & 13226 & 13226 \\
\hline Adj-R ${ }^{2}$ & 0.173 & 0.174 & \begin{tabular}{|l|}
0.174 \\
\end{tabular} & 0.171 & 0.172 & 0.173 \\
\hline $\mathrm{F}$ & 174.346 & 175.358 & 174.799 & 171.630 & 173.050 & 173.835 \\
\hline
\end{tabular}

Table 12. The Effect of Marketization Index on the Relationship between Eastern and Western Religion and Enterprise Innovation Output

\begin{tabular}{|c|c|c|c|c|c|c|}
\hline Variables & Patent & & & & & \\
\hline East100 & $\begin{array}{l}0.200 * * * \\
(5.284)\end{array}$ & & & & & \\
\hline East200 & & $\begin{array}{l}0.269 * * * \\
(6.320)\end{array}$ & & & & \\
\hline East300 & & & $\begin{array}{l}0.237 * * * \\
(5.737) \\
\end{array}$ & & & \\
\hline West100 & & & & $\begin{array}{l}0.259 * * * \\
(6.964)\end{array}$ & & \\
\hline West200 & & & & & $\begin{array}{l}0.348 * * * \\
(9.098)\end{array}$ & \\
\hline West300 & & & & & & $\begin{array}{l}0.354 * * * \\
(9.505)\end{array}$ \\
\hline Market & $\begin{array}{l}0.130^{* * * *} \\
(8.775)\end{array}$ & $\begin{array}{l}0.160^{* * *} \\
(10.293)\end{array}$ & $\begin{array}{l}0.165^{* * *} \\
(10.375) \\
\end{array}$ & $\begin{array}{l}0.116^{* * *} \\
(8.238)\end{array}$ & $\begin{array}{l}0.176^{* * *} \\
(10.410)\end{array}$ & $\begin{array}{l}0.193 * * * \\
(11.246)\end{array}$ \\
\hline East $100 *$ Market & $\begin{array}{l}-0.249 * * * \\
(-5.607)\end{array}$ & & & & & \\
\hline East200*Market & & $\begin{array}{l}-0.349^{* * * *} \\
(-7.003)\end{array}$ & & & & \\
\hline East300*Market & & & $\begin{array}{l}-0.325 * * * \\
(-6.648)\end{array}$ & & & \\
\hline West $100 *$ Market & & & & $\begin{array}{l}-0.273^{* * *} \\
(-6.354)\end{array}$ & & \\
\hline West200*Market & & & & & $\begin{array}{l}-0.421 * * * \\
(-8.993)\end{array}$ & \\
\hline West $300 *$ Market & & & & & & $\begin{array}{l}-0.429 * * * \\
(-9.406)\end{array}$ \\
\hline Intercept & $\begin{array}{l}-4.989^{* * * *} \\
(-16.011) \\
\end{array}$ & $\begin{array}{l}-5.121 * * * \\
(-16.373) \\
\end{array}$ & $\begin{array}{l}-5.100 * * * \\
(-16.270)\end{array}$ & $\begin{array}{l}-5.056^{* * * *} \\
(-16.208) \\
\end{array}$ & $\begin{array}{l}-5.356 * * * \\
(-17.014) \\
\end{array}$ & $\begin{array}{l}-5.429 * * * \\
(-17.207) \\
\end{array}$ \\
\hline Number of Obs & 13226 & 13226 & 13226 & 13226 & 13226 & 13226 \\
\hline Adj-R $R^{2}$ & 0.202 & 0.204 & 0.204 & 0.204 & 0.206 & 0.206 \\
\hline $\mathrm{F}$ & 210.874 & 212.547 & 212.494 & 212.387 & 214.925 & 215.516 \\
\hline
\end{tabular}




\section{Conclusion and Discussion}

\subsection{Conclusion}

This article selects religion as an entry point to the informal system, explores the relationship between religion and the input and output of innovation, and adds the political variable and marketization index as the moderating variables to further explore the impact of moderating variables imposed on the relationship between religion and innovation. The empirical results show that: firstly, the religion has a significant positive correlation with the innovation input and output, and proves that incentive mechanism of social capital, human capital and long-term preferences promote the innovation greater than suppression mechanism of the risk aversion. The result has not changed when the religion is divided into Eastern and Western religions, because the doctrine of different religions tends to be the same when the incentive mechanism plays a major role. Second, compared with the non-politically-linked enterprises, in the politically connected companies, the significant positive relationship between religion and innovation is weakened, showing the alternative relationship between politics and religion. Moreover, politics has more strongly inhibited the positive correlation between Western religions and innovation which is a stronger alternative between politics and western religions. Thirdly, in places where the degree of marketization is low, religion has a strong impetus to the innovation of enterprises. Where the degree of marketization is high, the promotion effect is weakened, which manifests the formal system of market index is also a substitution of informal system of religion.

\subsection{Limitations and Future Research}

Since the intensity of religion is measured by the number of local religious sites registered with listed companies, it is only an ambience after all, and the personal beliefs of the company's management will certainly be more convincing. However, the difficulty of obtaining personal religious belief data in China makes the research of this article have some limitations. This article is to explore the influence of the informal system of religion on the innovation of enterprises. There are still many research directions in this area in the future. On the one hand, the informal system includes many aspects and religion is only a part of it. Future research can explore the impact of other types of informal institutions on business innovation. On the other hand, business innovation is only part of the company's decision-making process, and there are many other possibilities that religion influence the internal governance and other aspects of corporate governance which can be good research directions for the future.

\section{Fund}

The research is funded by the National Natural Science Foundation of China (NSFC research grant number: 71602110)

\section{Reference}

Acs, Z. J., \& Audretsch, D. B. (1988). Innovation in large and small firms. Economics Letters, 78(4), 678-690.

Akerlof, G. A. (1980). A theory of social custom, of which unemployment may be one consequence. Quarterly Journal of Economics, 94(4), 749-775. https://doi.org/10.2307/1885667

Baysinger, B., \& Hoskisson, R. E. (1989). Diversification strategy and $\mathrm{r} \& d$ intensity in multiproduct firms. Academy of Management Journal, 32(2), 310-332. https://doi.org/10.2307/256364

Chen, D., Hu, X., Liang, S., Xin, F., \& University, N. (2013). Religious tradition and corporate governance. Economic Research Journal.

Dong, J., \& Gou, Y. N. (2010). Corporate governance structure, managerial discretion, and the r\&d investment in china . International Review of Economics \& Finance, 19(2), 180-188. https://doi.org/10.1016/j.iref.2009.10.001

Du Y. J., \& Feng W. T. (2014). Religions, Political Connections and Donations: Evidence from Chinese Listed Companies. Contemporary Finance, (6), 111-122.

Du, X. (2013). Does religion matter to owner-manager agency costs? evidence from china. Journal of Business Ethics, 118(2), 319-347. https://doi.org/10.1007/s10551-012-1569-y

Dyreng, S. D., Mayew, W. J., \& Williams, C. D. (2012). Religious social norms and corporate financial reporting. Journal of Business Finance \& Accounting, 39(7-8), 845-875. https://doi.org/10.1111/j.1468-5957.2012.02295.x

Fernandes, N. (2008). Ec: board compensation and firm performance: the role of "independent" board members. Journal of Multinational Financial Management, 18(1), 30-44. https://doi.org/10.1016/j.mulfin.2007.02.003

Glaeser, L., \& Glendon, S. (1998). Incentives, predestination and free will. Economic Inquiry, 36(3), 429-443. https://doi.org/10.1111/j.1465-7295.1998.tb01724.x

Gruber, J. (2005). Religious market structure, religious participation, and outcomes: is religion good for you? B.e.journal of Economic Analysis \& Policy, 5(1), 1454-1454. https://doi.org/10.1515/1538-0637.1454 
Hart, O., Shleifer, A., \& Vishny, R. W. (1997). The proper scope of government: theory and an application to prisons. Quarterly Journal of Economics, 112(4), 1127-1161. https://doi.org/10.1162/003355300555448

Hilary, G., \& Hui, K. W. (2008). Does religion matter in corporate decision making in America?. Social Science Electronic Publishing, 93(3), 455-473.

Iannaccone, L. R. (1998). Introduction to the economics of religion (vol 36, pg 1494, 1998). Journal of Economic Literature, 36(4), 1941-1941.

Johansson, S. O., Mahmud, M., \& Martinsson, P. (2009). Trust and religion: experimental evidence from rural bangladesh. Economica, 76(303), 462-485. https://doi.org/10.1111/j.1468-0335.2008.00689.x

Kam, W. P., Kiese, M., Singh, A., \& Wong, F. (2003). The pattern of innovation in singapore's manufacturing sector. Singapore Management Review.

Lei, G. Y., Liu M,, \& Cao, Y. L. (2016). Religious Beliefs, Political Identity and Corporate Investment Preferences. Financial Research, 42(6), 110-120.

Lelkes, O. (2002). Tasting freedom: happiness, religion and economic transition. Journal of Economic Behavior \& Organization, 59(2), 173-194. https://doi.org/10.1016/j.jebo.2004.03.016

Lerner, J. S., \& Keltner, D. (2001). Fear, anger, and risk. Journal of Personality \& Social Psychology, 81(1), 146. https://doi.org/10.1037/0022-3514.81.1.146

Mak, Y. T., \& Kusnadi, Y. (2005). Size really matters: further evidence on the negative relationship between board size and firm value. Pacific-Basin Finance Journal, 13(3), 301-318. https://doi.org/10.1016/j.pacfin.2004.09.002

Mcguire, S. T., Omer, T. C., \& Sharp, N. Y. (2011). The impact of religion on financial reporting irregularities. Accounting Review, 87(2), 645-673. https://doi.org/10.2308/accr-10206

Ng, A., Yuce, A., \& Chen, E. (2009). Determinants of state equity ownership, and its effect on value/performance: china's privatized firms. Pacific-Basin Finance Journal, 17(4), 413-443. https://doi.org/10.1016/j.pacfin.2008.10.003

Porta, R. L., Shleifer, A., \& Vishny, R. W. (1997). Trust in large organizations. American Economic Review, 87(2), 333-338.

Rokeach, M. (1968). Beliefs, attitudes, and values : a theory of organization and change. Revue Française De Sociologie, 11(3), 202-205.

Scherer, F. M. (1965). Firm size, market structure, opportunity, and the output of patented inventions. American Economic Review, 55(5), 1097-1125.

Shefer, D., \& Frenkel, A. (2005). R\&d, firm size and innovation: an empirical analysis. Technovation, 25(1), 25-32. https://doi.org/10.1016/S0166-4972(03)00152-4

Sørensen, J. B., \& Stuart, T. E. (2000). Aging, obsolescence, and organizational innovation. Administrative Science Quarterly, 45(1), 81-112. https://doi.org/10.2307/2666980

Sun, X. Y., \& Zhan, X. (2016). The Impact of Marketization on Regional Innovation Capacity and Regional Differences from the Perspective of Knowledge Flows. Techno-economics, 35(1), 36-42.

Vaona, A., \& Pianta, M. (2008). Firm size and innovation in european manufacturing. Small Business Economics, 30(3), 283-299. https://doi.org/10.1007/s11187-006-9043-9

Weaver, G. R., \& Agle, B. R. (2002). Religiosity and ethical behavior in organizations: a symbolic interactionist perspective. Academy of Management Review, 27(1), 77-97.

\section{Copyrights}

Copyright for this article is retained by the author(s), with first publication rights granted to the journal.

This is an open-access article distributed under the terms and conditions of the Creative Commons Attribution license which permits unrestricted use, distribution, and reproduction in any medium, provided the original work is properly cited. 